\title{
Analysis of cash holding for measuring the efficiency of cash management: A study on IT sector
}

\begin{abstract}
Somnath Das*
Assistant Professor in Commerce, Rabindra Mahavidyalaya, Champadanga, Hooghly-712401, India

C H R O N I C L E

Article history:

Received September 18, 2014

Accepted 15 December 2014

Available online

December 162014

Cash holding

Cash management

Trade off theory

Pecking order theory

\section{A B S T R A C T}

For measuring the efficiency of management of cash, cash holding is one of the most important financial decisions that the manager of the concerned organization, has to make in the organization. Basically, it is observed that the organization hold cash for future purposes is very negligible. If the organization invested cash in profitable securities then there is some flexibility but when it relates to the capital market holding cash is not advantageous. Generally two contradictory theories such as Trade-off theory and the Pecking order theory are considered for measuring the efficiency of cash management. In this study we generally observed measured the efficiency of Cash Management influenced by Cash Holding. We also measured whether cash holding of the organization is affected with the degree of financial leverage, size of the organization, investment and profitability. This study helps us to understand the influence of DFL, Investment and Size of the organization on Cash holding. Proper holding of cash in cash management can prevent the bankruptcy of any organization and also increases the efficiency of Cash or Liquidity management.
\end{abstract}

\section{Introduction}

For measuring the efficiency of Managing Cash, Cash Holding is one of the most important financial decisions that the manager of the concerned organization, has to make in the organization. Some organization holds more cash and some organization holds less cash. But how much Cash to hold is the question. For this different policies are framed. These policies have been regarded one of the most important financial policies in the process of managing Cash in the companies. Suppose, if we are in the world of Modigliani Miller then holding large amounts of is irrelevant because the organizations can easily collect funds from money markets or capital markets for their profitable investment projects at a very negligible transaction costs. At the time of inflow of cash, the manager may think whether it is distributed to the shareholder as dividend or purchase shares from market or keep it for future purposes. Generally, it is observed that the organization hold cash for future purposes is very negligible. During 1990-2003 the average level of cash in U.S firms was 22\% (Dittmar \& Mahrt-Smith, 2007). Cash holding may be good if the firm invests it in any profitable securities (Keynes, 1936) or in contrary 
there may be agency problem (Jensen, 1986). So regarding investment in profitable securities cash gives some flexibility but when it relates to the capital market holding cash is not advantageous.

Though, many international studies show that holding of cash is important for the growth of the companies. For example, Kalcheva and Lins (2003), found that companies hold an average amount of cash of their total assets or cash equivalents, Ferreira and Vilela (2003) found an average cash ratio of $15 \%$ and Guney et.al. (2003) observed that the average cash ratio of the company is $14 \%$. Therefore, a question rises, why companies hold cash? This question give birth two contradictory theories such as Trade-off theory (Myers, 1977) and the Pecking order theory (Myers \& Majluf, 1984). In the trade-off theory an optimal cash balance should be maintained, which results from weighting its marginal benefits and costs. On the other hand, pecking order theory, which is the extension work of trade off theory, does not believe the idea of optimal cash level. It is utilized as buffer between retained earnings and investment needs. Earlier studies like Opler et al. (1999) and Kim et al. (1998) supported the trade off theory. Cash level not only increases the growth opportunities of the company but also increases the business risk and capital expenditure. And it is difficult to operate in the capital market. On the other hand it decreases with its size, leverage and its dividend payments. Most of the studies supported the trade-off theory and shows that firm which have superior investor protection and in countries where capital markets are better developed hold less cash. Dittmar et al. (2002), Ferreira and Vilela (2003) and Guney et al. (2003) are the supporter of this type theory.

Like debt capital, cash holding generates costs and benefits; and it is very important in measuring the growth opportunities of the organization. Cash Holing acts as a safety buffer (Levasseur, 1979) which helps the organization to avoid the costs of raising external funds or liquidating existing assets and which allows the organization to finance their growth opportunities. In an imperfect market where the companies are operating, they have problem in accessing the capital markets and also bear a very important external financing cost. The main reason is that their environment is uncertain. Therefore, insufficient amount of cash forces the organization to forgo the profitable investment projects or to take loan at high rate of interest from market. Cash Holding includes two main costs. Such costs depend on whether managers want to maximize shareholders wealth or not. If managers want to increase shareholders' interests, the only cost of cash holdings is its lower return related to other investments in some external or internal projects of the same risk. If the managers do not want to maximize shareholders' wealth, then they increase their cash holdings to raise assets under their control and so increase their managerial diplomacy. In this case, the cost of cash holdings will increase and include the agency cost of managerial diplomacy. In Pecking order theory (Myers \& Majluf, 1984) there is no optimal cash level. It is used as a buffer between retained earnings and investment needs. According to this theory, the cash level would just depend upon the result of the financing and investment decisions. In this theory, due to asymmetries information issuing new equities is very costly for firms. Therefore, firms finance their investments primarily with the help of internal funds, then with debt and finally with equities. During higher cash inflow, firms use such cash flows to finance new profitable projects, to repay debts, to pay dividends and finally to accumulate cash. When retained earnings are insufficient to finance new investments, then firms use their cash holdings, and then issue new debt.

\section{Objectives of the study}

The present study is prepared to measure the efficiency of Cash Management of the selected companies in Indian IT sector in respect of their cash holding during the period of 2002-2011. Sufficient cash holding enables the organization to take the risk of borrowed capital, enlarge their assets position and investment to some profitable projects. Holding sufficient cash means sound liquidity. It helps the organization in meeting their contractual obligation when they are due. Higher amount holds by the organization as cash means better the position of liquidity. But excess holding cash can minimizes profitability. Profit cannot be forgone in order to maintain liquidity. Therefore, cash holding should be maintained in such a way that both profitability and liquidity are not affected and efficiency of Cash 
Management can be maintained. More specifically, the objectives of the study in this chapter are as follows.

(i) To measure the average cash holding of the selected companies from cash balance at the opening and at the end,

(ii) To measure the cash as percentage of total assets of the selected companies, deviation from the average cash holding of each of the selected companies using relevant statistical tools,

(iii) To rank the companies on the basis of average cash holding. Also, rank the companies on the basis of consistency and finally to rank the companies on the basis of both average and consistency jointly,

(iv) To measure the degree of relationship between the cash holding and degree of financial leverage, size of the organization, investment and profitability in each of the selected companies under study by using Pearson's simple correlation technique and to test such coefficients,

(v) To analyze the joint influence of DFL, Size of the organization and Investment on cash holding of the companies with the help of appropriate statistical measures like multiple regression analysis and to test the significance of such regression coefficients. Finally, to examine whether the companies are efficiently manage its cash or not.

\section{Methodology of the study}

Five popular companies from IT sector have been selected in this study. The data of the selected companies for the period 2002-2011 used in this study, have been taken from the secondary sources i.e. Capitaline Corporate Database of Capital Market Publishers (I) Ltd. Mumbai. Opening balance and closing balance of cash are used to determine the average cash balance of each year and again such cash balances are used to get the average cash holding. Large cash holding is preferable for better liquidity of the organization. In this study companies are ranked on the basis of average cash holding (cash as percentage of total assets) and consistency of cash holding and then ranking has been done considering the average cash holding and coefficients of variation (consistency) of average cash holding. In this study we examined the relationship between average cash holding and DFL, average cash holding and Investment and average cash holding and profitability (RONW). Degree of financial leverage (DFL) is computed with the help of the following formula,

$$
\mathrm{DFL}=\text { Operating Profit (EBIT) / (Operating Profit }- \text { Interest) }
$$

Financial leverage arises due to use of fixed charges bearing capital in the capital structure like debt capital. More debt capital means higher financial leverage. DFL measures the financial risk of the business. DFL affect the cash holding of the organization. More external borrowing means more cash holding. It can also be said that external borrowing replaces cash holding. Size of the organization has been calculated by the amount equal to the log value of total assets. Size of the organization can influence the corporate cash holding. Generally, small firms hold more cash not only for higher costs of use of external funds but also for borrowing constraints. But large organizations having too many expenses require large cash holding. Investment of the organization has been represented through the figure equal to the log value of total amount of Investment. Organization which have numerous investment opportunities but uncertain internal cash flow hold more cash otherwise borrowing external funds for profitable investment opportunity is too much costly. In this study profitability has been measured by the return on net worth (RONW). General principle is that higher the liquidity lowers the profitability. Holding more cash increases the short-term debt paying capacity of the organization, but decreases the profitability by not using the excess or unused fund in some other profitable projects. It also affect the efficiency of Cash Management. For analyzing the data statistical tools like arithmetic mean, standard deviation, coefficient of variation etc. and statistical techniques like Pearson's simple correlation analysis and multiple regression analysis and statistical test like ' $t$ ' test have been applied in appropriate places. 


\subsection{Limitations of the study}

(1) The study is based only on the date contained in published financial statements.

(2) Only the average cash holding and cash as percentage of total assets is considered in the study.

(3) The impact of some common macroeconomic factors or general factors is not considered in the study for the sake of simplicity.

(4) The multicollinearity factors can be existed in the multiple regression analysis for which no treatment has been done.

(5) More companies can be selected from but for simplicity, lack of time and unavailability of data it is not possible to select all companies for general comment.

\section{Findings of the study}

From Table 1 it is found that the average cash holding $(\mathrm{ACH})$ of Philips India Ltd. (Philips) is highest in the year 2008 (Rs.596.25 Crore) and lowest in the year 2002 (Rs. 13.3 Crore). On an average it is Rs.292 Crore. During the first half of the study period the ACH of Philips followed an increasing trend while in the second half of the study period a fluctuating trend is noticed. But, in the year 2009, the average cash holding as percentage of total assets of the company is highest i.e. $65.66 \%$. It indicates that the liquidity position in respect of $\mathrm{ACH}$ is best in the year 2008 as compared to other years whereas in respect of average cash holding as percentage of total assets it is sound in the year 2009. Table 1 shows that the ACH of Asian Electronics Ltd. (Asian) is highest in the year 2007 (Rs. 21.885Crore) and lowest in the year 2005 (Rs.0.065Crore). On an average it is Rs. 5.92 Crore. A fluctuating trend in the ACH is noticed during the study period of Asian. The highest percentage of cash holding on total assets is noticed in 2007(7.39\%).It indicates that the company maintained a very low level of cash. It may be due to higher cost of borrowing of external funds or investment in other projects. In case of Wipro Ltd. (Wipro), the picture is quite different. The ACH of Wipro is highest in 2011 (Rs.5433.8 Crore) and lowest in 2004 (Rs.349.895Crore). On an average it is Rs. 2083crore. Except the year 2002 and 2003 the company registered an increasing trend of ACH during the study period. The average cash holding as percentage of total assets is highest in 2009(23.22\%). It signifies moderate liquidity condition of the company.

Table 1

Calculation of Average Cash Holding (Avg. cash holding as percentage of total assets) of Selected Companies of IT Sector Rs. in crore (also in \% of total assets)

\begin{tabular}{|c|c|c|c|c|c|c|c|c|c|c|c|}
\hline \multirow{2}{*}{ COMPANIES } & \multicolumn{10}{|c|}{ Years } & \multirow{2}{*}{ AVG. } \\
\hline & 2002 & 2003 & 2004 & 2005 & 2006 & 2007 & 2008 & 2009 & 2010 & 2011 & \\
\hline PHILIPS & $\begin{array}{c}13.3 \\
(5.96)\end{array}$ & $\begin{array}{c}46.3 \\
(12.68)\end{array}$ & $\begin{array}{c}107 \\
(28.25)\end{array}$ & $\begin{array}{c}170.2 \\
(33.03)\end{array}$ & $\begin{array}{c}176.35 \\
(30.26)\end{array}$ & $\begin{array}{c}335.3 \\
(43.07)\end{array}$ & $\begin{array}{l}596.25 \\
(62.43)\end{array}$ & $\begin{array}{l}590.35 \\
(65.66)\end{array}$ & $\begin{array}{l}466.55 \\
(56.88)\end{array}$ & $\begin{array}{l}413.45 \\
(46.41)\end{array}$ & $\begin{array}{c}292 \\
(38.5)\end{array}$ \\
\hline ASIAN & $\begin{array}{c}6.02 \\
(3.05)\end{array}$ & $\begin{array}{c}2.6 \\
(1.26)\end{array}$ & $\begin{array}{c}3.13 \\
(1.69)\end{array}$ & $\begin{array}{c}0.07 \\
(0.03)\end{array}$ & $\begin{array}{c}7.29 \\
(3.83)\end{array}$ & $\begin{array}{l}21.88 \\
(7.39)\end{array}$ & $\begin{array}{c}4.06 \\
(0.786)\end{array}$ & $\begin{array}{c}4.49 \\
(1.06)\end{array}$ & $\begin{array}{c}5.32 \\
(1.16)\end{array}$ & $\begin{array}{c}4.40 \\
(1.20)\end{array}$ & $\begin{array}{c}5.92 \\
(2.15)\end{array}$ \\
\hline WIPRO & $\begin{array}{l}370.21 \\
(14.46)\end{array}$ & $\begin{array}{c}351.6 \\
(10.34)\end{array}$ & $\begin{array}{c}349.90 \\
(9.69)\end{array}$ & $\begin{array}{l}413.5 \\
(8.35)\end{array}$ & $\begin{array}{l}679.95 \\
(10.50)\end{array}$ & $\begin{array}{c}1336.1 \\
(13.97)\end{array}$ & $\begin{array}{c}2790.65 \\
(18.08)\end{array}$ & $\begin{array}{c}4070.65 \\
(23.22)\end{array}$ & $\begin{array}{l}5036.8 \\
(21.69)\end{array}$ & $\begin{array}{l}5433.8 \\
(20.85)\end{array}$ & $\begin{array}{c}2083 \\
(15.1)\end{array}$ \\
\hline $\mathrm{CMC}$ & $\begin{array}{c}19.25 \\
(16.08)\end{array}$ & $\begin{array}{c}19.25 \\
(11.07)\end{array}$ & $\begin{array}{c}18.81 \\
(8.15)\end{array}$ & $\begin{array}{l}15.33 \\
(5.95)\end{array}$ & $\begin{array}{c}19.7 \\
(7.04)\end{array}$ & $\begin{array}{c}31.16 \\
(12.46)\end{array}$ & $\begin{array}{c}77.57 \\
(23.33)\end{array}$ & $\begin{array}{l}136.48 \\
(32.72)\end{array}$ & $\begin{array}{l}184.88 \\
(38.79)\end{array}$ & $\begin{array}{l}237.95 \\
(39.85)\end{array}$ & $\begin{array}{c}76 \\
(19.6)\end{array}$ \\
\hline VIDEOCON & $\begin{array}{l}155.76 \\
(16.36)\end{array}$ & $\begin{array}{c}156.6 \\
(10.79)\end{array}$ & $\begin{array}{c}137.99 \\
(8.49)\end{array}$ & $\begin{array}{l}138.1 \\
(5.21)\end{array}$ & $\begin{array}{c}159.89 \\
(5.47)\end{array}$ & $\begin{array}{c}181.84 \\
(5.56)\end{array}$ & $\begin{array}{l}219.08 \\
(6.43)\end{array}$ & $\begin{array}{c}202.97 \\
(5.2)\end{array}$ & $\begin{array}{c}168.71 \\
(3.61)\end{array}$ & $\begin{array}{l}148.8 \\
(3.12)\end{array}$ & $\begin{array}{c}167 \\
(6.43)\end{array}$ \\
\hline
\end{tabular}

Table 1 shows that the ACH of CMC Ltd. (CMC) is highest in the year 2011 (Rs.237.95Crore) and lowest in the year 2005 (Rs.15.33 Crore). On an average it is Rs. 76 Crore. Except the year 2002, 2003 and 2004 an increasing trend in $\mathrm{ACH}$ is noticed during the study period. On the other hand cash holding as percentage of total assets is highest in 2011(39.85\%). From table-1 we can conclude that the company improved its liquidity position during the last part of the study period. It is found from Table 1 that the ACH of Videocon Group is highest in the year 2008 (Rs.219.08 Crore) and lowest in the year 2005 (Rs.138.1 Crore). On an average it is Rs. 167 Crore. The ACH of Videocon fluctuated during the study period. Cash holding as percentage of total assets is highest in the year 2003(10.79\%). The company maintained a low level of cash throughout the study period. It indicates that the company 
maintained a low liquidity level throughout the study period. Therefore, among five companies from IT sector Wipro maintained higher level of cash throughout the study period and it helped the company to improve their liquidity position. Fig. 1 also discloses that the average level of Cash Holding of Wipro is increases throughout study period than other companies of IT sector.

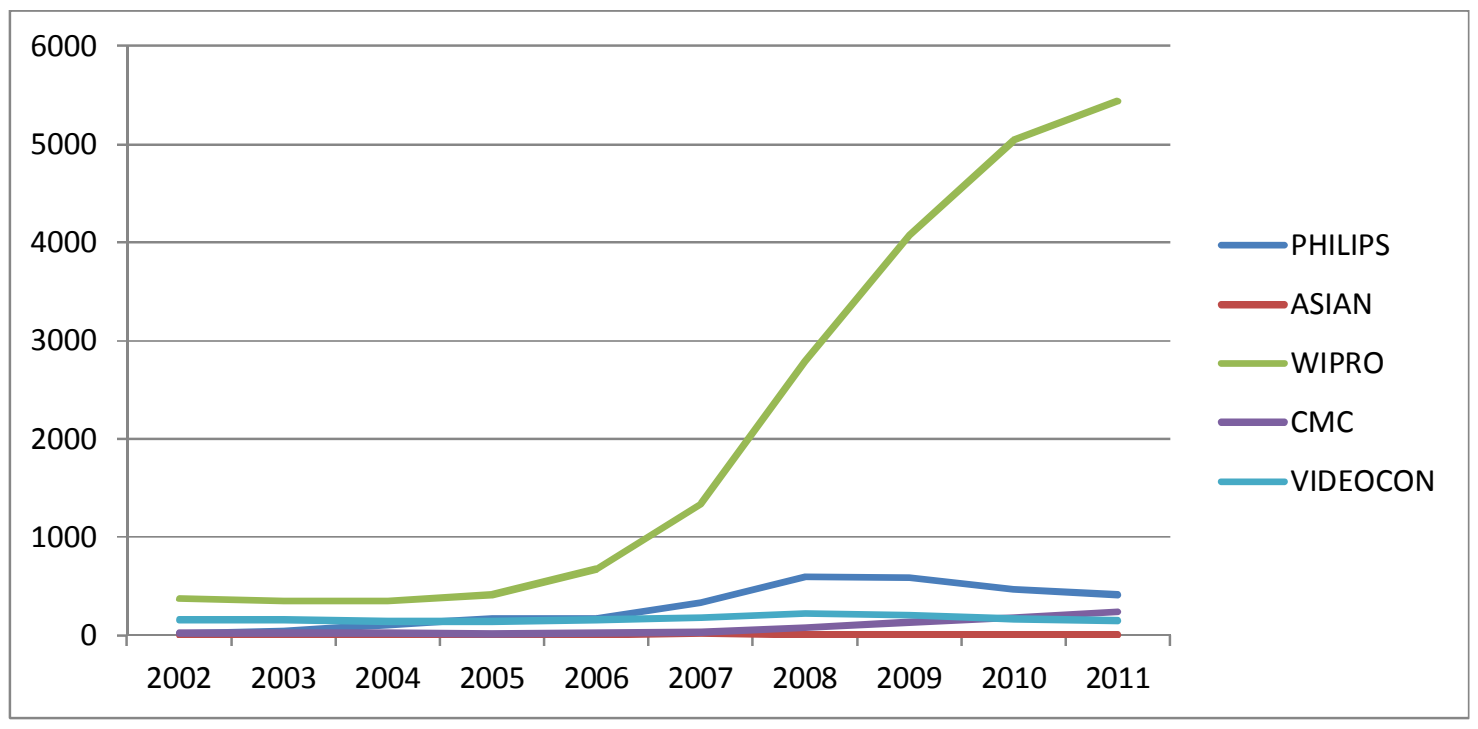

Fig. 1. Trend of cash holding

In Table 2 the values of average cash holding as percentage of total assets of the companies under study have been ascertained by applying arithmetic mean and consistency of $\mathrm{ACH}$ have also been measured by using the coefficient of Variation (CV) of their average cash holding. It is found from table-2 that in IT sector the average cash holding as percentage of total assets of Philips is the highest, followed by $\mathrm{CMC}$, Wipro, Videocon and Asian respectively in that order. The table also reveals that in respect of consistency of designing average cash holding, Videocon captured the top most position and it is followed by Philips, Wipro, Asian and CMC respectively. Combining both average and consistency aspect together Philips occupied the first rank whereas Videocon has got the second rank, followed by Wipro, CMC and Asian in that order.

\section{Table 2}

Statement Showing Ranking on the basis of Average and Consistency of Average Cash Holding of the Selected Companies from IT Sector

\begin{tabular}{lccccccc}
\hline Companies & $\begin{array}{c}\text { Avg. Cash as \% } \\
\text { of Total Assets }\end{array}$ & SD & $\begin{array}{c}\text { Rank of } \\
\text { Avg. }\end{array}$ & $\begin{array}{c}\text { Coefficients of } \\
\text { variation }\end{array}$ & $\begin{array}{c}\text { Rank of } \\
\text { Coefficients }\end{array}$ & $\begin{array}{c}\text { Total } \\
\text { Rank }\end{array}$ & $\begin{array}{c}\text { Over all } \\
\text { Rank }\end{array}$ \\
\hline PHILIPS & 38.5 & 207.2 & 1 & 71.07 & 2 & 3 & 1 \\
ASIAN & 2.15 & 5.64 & 5 & 95.19 & 4 & 9 & 5 \\
WIPRO & 15.1 & 1966 & 3 & 94.37 & 3 & 6 & 3 \\
CMC & 19.6 & 77.69 & 2 & 102.2 & 5 & 7 & 4 \\
VIDEOCON & 6.43 & 25.54 & 4 & 15.3 & 1 & 5 & 2 \\
\hline
\end{tabular}

It has been found from Table 3 that the correlation coefficient between Average Cash Holding and Degree of financial leverage (DFL) in Philips, Asian, Wipro, CMC, Videocon are 0.723, 0.072, 0.660, (-) 0.774 and 0.379 respectively. Out of which the correlation coefficient between ACH and DFL in Philips, Asian, Wipro and Videocon Ltd is positive and the same in Philips and Wipro is statistically significant at 5\% level. It implies the strength of positive association between ACH and DFL in Asian, Videocon, Philips and Wipro and correlation Coefficient of last two companies is highly significant. But, the correlation coefficient in case of CMC Ltd is negative and statistically significant both at 5\% and $1 \%$ level of significance. It follows the theoretical principle. 
Table 3

Statement Showing Karl Pearson's Simple Correlation Analysis between AVG Cash Holding and DFL, Size of Org., Investment and RONW of the Selected Companies from IT Sector

\begin{tabular}{|c|c|c|c|c|c|c|c|c|}
\hline \multirow[t]{2}{*}{ COMPANIES } & \multicolumn{2}{|c|}{$\begin{array}{c}\text { AVG CASH HOLDING \& } \\
\text { DFL }\end{array}$} & \multicolumn{2}{|c|}{$\begin{array}{l}\text { AVG CASH HOLDING \& } \\
\text { SIZE OF ORG. }\end{array}$} & \multicolumn{2}{|c|}{$\begin{array}{c}\text { AVG CASH HOLDING } \\
\& \\
\text { INVESTMENT }\end{array}$} & \multicolumn{2}{|c|}{$\begin{array}{c}\text { AVG CASH HOLDING \& } \\
\text { RONW }\end{array}$} \\
\hline & $(\mathrm{r})$ & 't' Value & $(\mathrm{r})$ & 't' Value & $(\mathrm{r})$ & 't' Value & $(\mathrm{r})$ & 't' Value \\
\hline PHLIPS & $0.723^{*}$ & 2.96 & $0.980 * *$ & 13.929 & -0.155 & -0.444 & $-0.839 * *$ & -4.36 \\
\hline ASIAN & 0.072 & 0.2 & 0.356 & 1.0775 & 0.499 & 1.629 & 0.274 & 0.806 \\
\hline WIPRO & $0.660^{*}$ & 2.48 & $0.983 * *$ & 15.143 & $0.842 * *$ & 4.415 & -0.429 & -1.34 \\
\hline $\mathrm{CMC}$ & $-0.774 * *$ & -3.5 & $0.861 * *$ & 4.7881 & $0.978 * *$ & 13.26 & 0.199 & 0.574 \\
\hline VIDEOCON & 0.379 & 1.16 & 0.433 & 1.3587 & 0.218 & 0.632 & -0.325 & -0.97 \\
\hline
\end{tabular}

Note: Figures in the parentheses indicate ' $t$ ' values.

It has been found from Table 3 that the correlation coefficient between Average cash holding (ACH) and size of the organization in Philips, Asian, Wipro, CMC, and Videocon are 0.980, 0.356, 0.983, 0.861 and 0.433 respectively. All the correlation coefficients are positive and out of which the same in case of Philips, Wipro and CMC Ltd is statistically significant both at 5\% and $1 \%$ level. It implies that the ACH and Size of the organization is positively related in case of all the companies in IT sector selected in the study. It is observed from Table 3 that the correlation coefficient between Average Cash Holding (ACH) and Investment in Philips, Asian, Wipro, CMC, and Videocon are (-) 0.155, 0.499, $0.842,0.978$ and 0.218 respectively. Out of which the correlation coefficients between ACH and Investment in Asian, Wipro, CMC and Videocon are positive. The coefficients in case of Wipro and $\mathrm{CMC}$ are highly significant both at $5 \%$ and $1 \%$ level. It implies high positive association between $\mathrm{ACH}$ and Investment among the four companies in IT sector mentioned above. The correlation coefficient in Philips is negative. It shows the negative association between $\mathrm{ACH}$ and Investment in Philips. It has been observed from Table 3 that the correlation coefficient between Average Cash Holding (ACH) and profitability (RONW) in Philips, Asian, Wipro, CMC and Videocon are (-) 0.839, 0.274, (-) 0.429, 0.199 and (-) 0.325 respectively. In these correlation coefficients, the same in Philips, Wipro and Videocon is negative. The correlation coefficient of Philips is also significant both at $5 \%$ and $1 \%$ level of significance. It implies that in Philips, Wipro and Videocon, the ACH is negatively associated with RONW. On the other hand, there is a low positive association between ACH and RONW in Asian and $\mathrm{CMC}$ is observed from table-3. It indicates that in Asian and in $\mathrm{CMC}$ the association between $\mathrm{ACH}$ and RONW is positive.

\section{Table 4}

Statement Showing Multiple Regression of Avg Cash Holding on DFL, Size of Org. and Investment of the Selected Companies of IT Sector Regression Equation is Avg. Cash Holding $=a_{0}+a_{1}$ DFL $+a_{2}$ Size of Org. $+a_{3}$ Investment

\begin{tabular}{|c|c|c|c|c|c|}
\hline \multirow[b]{2}{*}{ COMPANIES } & \multicolumn{3}{|c|}{ PARTIAL REGRESSION COEFFICIENT } & \multirow[b]{2}{*}{ CONSTANT } & \multirow[b]{2}{*}{$\mathrm{R}_{\mathrm{ED}}^{2}$} \\
\hline & DFL & SIZE OF THE ORGANISTION & INVESTMENT & & \\
\hline PHLIPS & $0.255(1.560)$ & $2.205(9.133)^{* * *}$ & $0.049(0.689)$ & $-4.080(-7.159)$ & 0.973 \\
\hline ASIAN & $-0.127(-0.876)$ & $-0.752(-0.385)$ & $0.518(1.373)$ & $2.414(0.509)$ & 0.336 \\
\hline WIPRO & $1.955(1.211)$ & $1.750(11.408) * * *$ & $-0.448(-3.506)^{* * *}$ & $-4.182(-2.837)$ & 0.991 \\
\hline $\mathrm{CMC}$ & $-2.938(-1.770)$ & $0.527(1.644)$ & $0.442(3.372)^{* * *}$ & $2.771(1.734)$ & 0.974 \\
\hline VIDEOCON & $0.046(0.301)$ & $0.111(0.671)$ & $0.107(0.519)$ & $1.514(2.370)$ & 0.236 \\
\hline
\end{tabular}

In Table 4 an attempt has been made to assess the influence of DFL, Size of the organization and Investment on Average Cash Holding. In this study DFL has been taken as the measure of financial risk, log value of total assets has been taken as the measure of size of the organization and log value of total investment has been taken as the measure of Investment. The linear regression equation has been fitted in this study as $A C H=b_{0}+b_{1} D F L+b_{2}$ Size of the org. $+b_{3}$ Investment, where, $b_{0}$ is the value of intercept term (constant) and $b_{1}, b_{2}$ and $b_{3}$ are the slopes of the line, i.e. the regression coefficient of $\mathrm{ACH}$ on DFL, Size of the organization and Investment respectively. This regression equation has been tested by ' $t$ ' test. It has been found from Table 4 that for one unit increase in DFL the ACH of Philips 
stepped up by only 0.255 units, which is statistically insignificant. The above table also reveals that for one unit increase in the size of the organization the ACH of Philips gone up by 2.205 units which is found to be statistically significant at $1 \%$ level. Table 4 exhibits that for one unit increase in Investment, the ACH of Philips goes up by only 0.049 units, which is also statistically insignificant. It implies that the influence of DFL, Size of the organization and Investment on ACH is positive. The coefficient of determination $\left(\mathrm{R}^{2}\right)$ makes it clear that $97.3 \%$ of the variation of the company's $\mathrm{ACH}$ is accounted for by the variation in DFL, Size of Org and Investment.

Table 4 exhibits that, for one unit increase in DFL, the ACH of Asian Electronic Ltd. is go down by only 0.127 units which is also statistically insignificant. It is revealed from table-10 that for one unit increase in size of the organization the $\mathrm{ACH}$ of Asian go down by only 0.752 units which is insignificant. Table-4 also shows that for one unit increase in Investment the ACH of the company stepped up by only 0.518 unit which is insignificant. It signifies that the influence of Investment on $\mathrm{ACH}$ is positive but not statistically significant whereas the influence of DFL and size of the organization on $\mathrm{ACH}$ is negative. The coefficient of determination $\left(\mathrm{R}^{2}\right)$ makes it clear that $33.6 \%$ of the variation of the company's ACH is accounted for by the variation in DFL, Size of Organization and Investment. It is found from Table 4 that for one unit increase in DFL the ACH of Wipro stepped up by 1.955 units which is statistically insignificant. Table 4 depicts that for one unit increase in size of organization, the ACH of Wipro increased by 1.750 units which is statistically significant at $1 \%$ level. Table 4 also reveals that for one unit increase in Investment the ACH of Wipro go down by only 0.448 units which is statistically significant at $1 \%$ level. It indicates that the influence of DFL and size of the organization on $\mathrm{ACH}$ is positive and statistically significant while Investment is negatively influenced the ACH of Wipro. The coefficient of determination $\left(\mathrm{R}^{2}\right)$ makes it clear that $99.1 \%$ of the variation of the company's ACH is accounted for by the variation in DFL, Size of Organization and Investment. The Table 4 depicts that for one unit increase in DFL, the ACH of CMC decreased by 2.938 units which is statistically insignificant. It is also found from table-4 that for one unit increase in size of the organization the ACH of CMC Ltd increased by 0.527 units which is statistically insignificant. It is also found from Table 4 that for one unit increase in Investment, the ACH of CMC increased by 0.442 units which is statistically significant at $1 \%$ level. It indicates that size of the organization and Investment of Wipro are positively influenced the ACH whereas DFL of the company is negatively influenced the $\mathrm{ACH}$. The coefficient of determination $\left(\mathrm{R}^{2}\right)$ makes it clear that $97.4 \%$ of the variation of the company's ACH is accounted for by the variation in DFL, Size of Org and Investment. It is revealed from Table 4 that for one unit increases in DFL, the ACH of Videocon increased by 0.046 units which is statistically insignificant. Table 4 portrays that for one unit increase in size of the organization, the ACH of Videocon stepped up by only 0.111 units which is also insignificant. Table4 also displays that for one unit increase in Investment the ACH of Videocon is gone up by 0.107 units which is insignificant. It implies that the influence of DFL, Size of the organization and Investment on $\mathrm{ACH}$ is positive. The coefficient of determination $\left(\mathrm{R}^{2}\right)$ makes it clear that $23.6 \%$ of the variation of the company's ACH is accounted for by the variation in DFL, Size of Org and Investment. Therefore, from table-4 it is clear that in case of both Philips and Videocon the influence of DFL, Size of the organization and Investment on $\mathrm{ACH}$ are positive.

\section{Conclusion}

For measuring the efficiency of Cash Management, Cash Holding is an important decision, a financial manager has to make. At the time of inflow of cash the manager may think whether it is distributed to the shareholder as dividend or purchase the shares from market or keep it for future purposes. Generally, it is observed that the organization hold cash for future purposes is very negligible. Past experience suggest that growth firm holds more cash than matured firms. It can also be opined that growth firms and matured firms have different needs for holding cash. Cash holding is negatively related with the firm's characteristics, size, level of liquid assets and short-term debt. For matured firms the holding of cash depends on the form of dividends or stock repurchased and decreases with their research and development expenses. Practically, cash level of matured companies increases with their 
investment level. It is also found that cash level of matured companies is negatively related with trade credit. In this study it is found that average cash holding of Wipro is best but from the point of view of cash as percentage of total assets, Philips captured the top position. It signifies the greater liquidity position. And as the firm is growing, it supported the theoretical aspect also. On the basis of ranking, considering both average cash holding as $\%$ of total assets and coefficient of variation of Cash Holding Philips is best. It also supported the theoretical argument that greater liquidity means efficient management of cash. It is observed from the study that only in case of CMC, DFL is negatively related with AVG Cash Holding, it supported the theoretical proposition. But in other cases the relationship is positive. From our study it is depicted that in all the companies Average Cash Holding is positively related with size of the organization. It signifies that as size of the organization increases, the companies are holding more cash. It is also found from our study that except Philips all the companies under study, Investment is positively related with Average Cash Holding. It portrays that these companies having excess fund might invested in some profitable projects. It also supported the theoretical argument. It is observed from our study that all the selected companies except Asian Electronics Ltd and CMC, Average Cash Holding is negatively related with Return on Net Worth. It also supported the theoretical proposition. From the study it is observed that in case of Philips and Videocon all the three factors positively influenced the Average Cash Holding. In other cases some factors influenced the Average Cash Holding positively and some factors influenced the Average Cash Holding negatively. It also supported the theoretical assumption. Finally, we can conclude that from the point of view of Cash Holding Philips and Videocon are efficiently managed their Cash.

\section{References}

Bari, R. R. (Ed.). (1981). Selected Readings in Cash Management. Triveni Publications.

Bradley, J. F. (1974). Administrative financial management. Dryden Press.

Cohen, J. B., \& Robbins, S. M. (1966). The financial manager: basic aspects of financial Administration. Harper \& Row.

Dittmar, A., \& Mahrt-Smith, J. (2007). Corporate governance and the value of cash holdings. Journal of Financial Economics, 83(3), 599-634.

Fazzari, S. M., \& Petersen, B. C. (1993). Working capital and fixed investment: new evidence on financing constraints. The RAND Journal of Economics, 24(3), 328-342.

Ferreira, M. A., \& Vilela, A. S. (2004). Why do firms hold cash? Evidence from EMU countries. European Financial Management, 10(2), 295-319.

Guney, Y., Ozkan, A., \& Ozkan, N. (2007). International evidence on the non-linear impact of leverage on corporate cash holdings. Journal of Multinational financial management, 17(1), 45-60.

Keynes, J. M. (2006). General theory of employment, interest and money. Atlantic Publishers \& Dist.

Levasseur, M. (1979). Gestion de trésorerie. Economica.

Van Horne, J. C. (1968). Financial management and policy (pp. 254-71). Prentice-Hall.

Kalcheva, I., \& Lins, K. V. (2007). International evidence on cash holdings and expected managerial agency problems. Review of Financial Studies, 20(4), 1087-1112.

Kim, C. S., Mauer, D. C., \& Sherman, A. E. (1998). The determinants of corporate liquidity: Theory and evidence. Journal of financial and quantitative analysis, 33(3), 335-359.

Myers, S. C. (1977). Determinants of corporate borrowing. Journal of financial economics, 5(2), 147-175.

Myers, S. C., \& Majluf, N. S. (1984). Corporate financing and investment decisions when firms have information that investors do not have. Journal of financial economics, 13(2), 187-221.

Opler, T., Pinkowitz, L., Stulz, R., \& Williamson, R. (1999). The determinants and implications of corporate cash holdings. Journal of financial economics,52(1), 3-46.

Pandey, I. M. (1999). Financial Management-Vikas Publishing House Pvt.Ltd-.

Ramamoorthy, V. E. (1978). Working Capital Management, Madras: Institute of Financial Management and Research, 5.

Solomon, E., \& Pringle, J. J. (1981). An introduction to financial management. Scott, Foresman.

Weinraub, H. J., \& Visscher, S. (1998). Industry practice relating to aggressive conservative working capital policies. Journal of Financial and Strategic Decision, 11(2), 11-18.

Whited, T. M. (1992). Debt, liquidity constraints, and corporate investment: Evidence from panel data. The Journal of Finance, 47(4), 1425-1460. 